\title{
Research on the Cultivation of Comprehensive Quality and Innovative Ability of Applied Talents
}

\author{
Deng Haisheng \\ College of information and Engineer, Xijing University, Shaanxi Xi'an 710123
}

Keywords: applied talents; comprehensive quality; innovative ability

Abstract: Innovative ability is the core competitiveness of talents, and comprehensive quality is the basic condition of innovative ability. This paper discusses the concept and requirements of training applied talents, constructs the curriculum system of training applied comprehensive quality and innovative ability around the training specifications, and probes into the reform of teaching methods, management system and operation mechanism of training applied talents' comprehensive quality and innovative ability.

In recent years, with the continuous improvement of the teaching scale and quality of colleges and universities, it is very important to increase the teaching research and practice of undergraduate colleges and universities. Newly-built undergraduate colleges and universities have innate advantages, which can quickly adapt to market demand and train a group of first-class application-oriented talents with excellent innovation ability and comprehensive quality.

\section{The idea and specification requirements of training applied talents}

Applied talents need to master the existing production technology and equipment technology, which can solve the practical problems in production, have advanced awareness and the potential to seize opportunities, flexibly apply the latest theoretical results and turn them into products, and have the ability of sustainable development. As a specification requirement, it should possess the following characteristics, As shown in Table 1:

Before formulating the training plan, the specialties should study the layout of the specialty in the whole country and the region, the training objectives and characteristics of the courses offered by the schools, collect and investigate the needs and specifications of the specialists in the region, and study and determine the training objectives and design the training specifications in the light of the background and conditions of the school's disciplines and specialties. For example, after studying the development history, professional background and potential of the specialty, combined with the social requirements for professional training, the specialty of mechanical design, manufacturing and automation in our university has determined the goal of talent training, that is, to train the equipment and technology leaders in the front line of service production, the future section leaders or the technical directors in the workshop. 
Table 1 Characteristics of Applied Talents

\begin{tabular}{|c|c|}
\hline Characteristic & Details \\
\hline $\begin{array}{c}\text { having a strong basic theoretical } \\
\text { knowledge. }\end{array}$ & $\begin{array}{c}\text { Basic theoretical knowledge is the premise of innovation and the } \\
\text { basis of development. }\end{array}$ \\
\hline $\begin{array}{c}\text { Strong professional knowledge job skills. } \\
\text { and }\end{array}$ & $\begin{array}{c}\text { The practical ability and operation skill of engineering practice is } \\
\text { an important characteristic that distinguishes applied talents from } \\
\text { other talents. To be sensitive to discovering and identifying } \\
\text { problems, we should be skilled in using all kinds of knowledge } \\
\text { and skills to solve practical problems on the spot. }\end{array}$ \\
\hline $\begin{array}{c}\text { Strong sense of innovation and } \\
\text { creativity. }\end{array}$ & $\begin{array}{c}\text { Innovation and creation are the core characteristics of all levels of } \\
\text { talents. The cultivation of applied talents should focus on the } \\
\text { cultivation of innovative consciousness, encourage innovation and } \\
\text { change, encourage innovation and imitation creation, be flexible } \\
\text { in applying the knowledge learned to analyze and research, } \\
\text { creatively solve practical problems, put forward new ideas and } \\
\text { develop new products. According to the specifications of applied } \\
\text { talents, different schools and majors have specific requirements } \\
\text { and regulations. The author believes that under the concept of } \\
\text { training applied talents in schools, each specialty has its own } \\
\text { advantages and characteristics. }\end{array}$ \\
\hline
\end{tabular}

2. The problems existing in the education and teaching of undergraduate colleges and universities in china

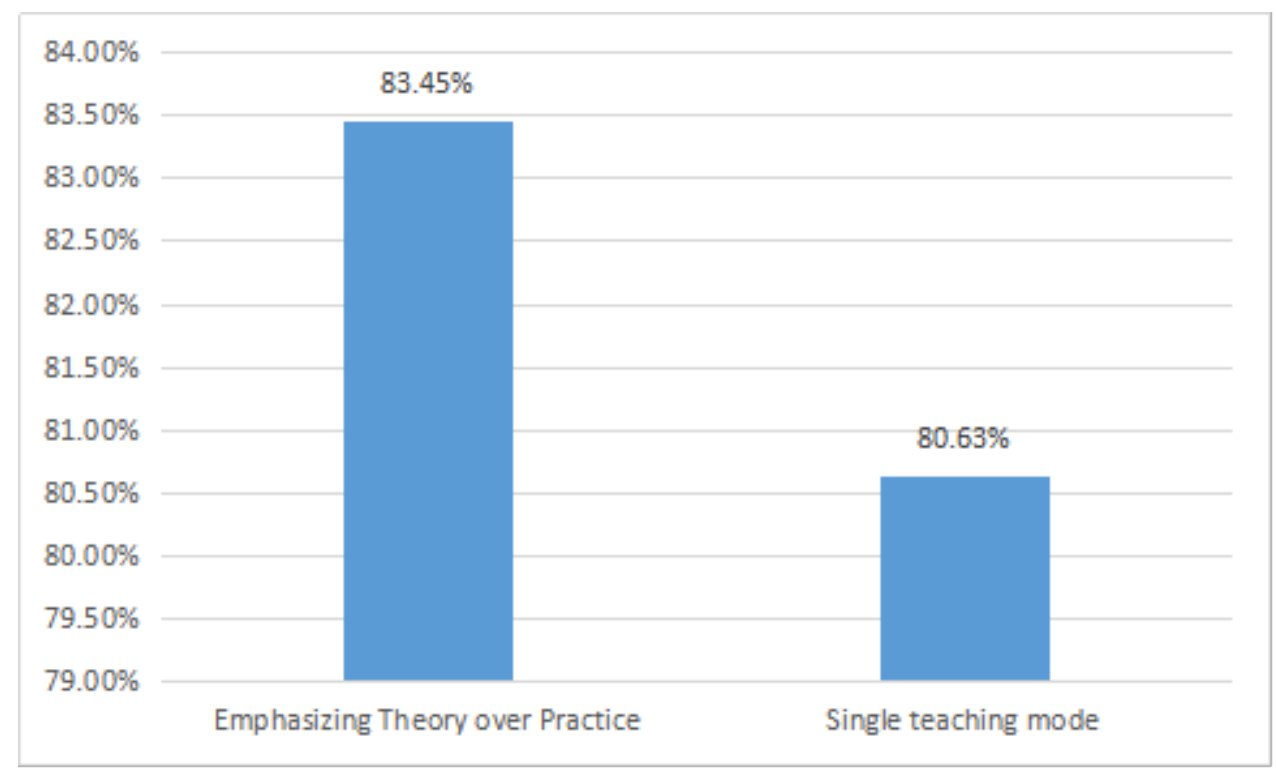

Figure 1 Problems in Education and Teaching

As shown in figure 1, the problems in school education and teaching will be analyzed below.

\subsection{Undergraduate colleges and universities attach great importance to theory rather than practice, and attach great importance to reserve rather than ability}

In the tradition of college teaching and the subconscious of teachers, the main task is usually to train "reserve talents", but little attention is paid to "knowledge and ability talents". Too much attention is paid to the storage of studentship knowledge, so that students do not have the courage 
and will to innovate. In traditional teaching, the way of practice is single, and the boring practice makes many students unwilling to try. This practice lacks pertinence, fun and versatility.

\subsection{Single teaching model}

Teachers do not attach great importance to the individualization and differentiation of students in the teaching process, which limits the development of each student's individuality. If we want to solve this kind of teaching problem, teachers should leave more time for students to create their own knowledge in the process of practice. At the same time, it can also stimulate the potential of students and burst out the brilliance of knowledge.

3. Innovation of teaching management and operation mechanism is the guarantee of cultivating comprehensive quality and innovative ability of applied talents

\subsection{Reform the teaching management system and implement flexible education system to meet the individual needs of students}

Students can determine their learning arrangements according to their interests and actual situation, choose courses, so that they can learn well, learn useful, learn to achieve success, and improve uninteresting in learning. We should improve the system of specialty transfer and promote the mode of "major and minor, double degree" education. Students can adjust their professional applications according to their specialties, interests and employment intentions. Schools provide students with opportunities for free development, help students choose their own specialties and courses from their own perspective, and expand their professional knowledge and development potential. Perfect "Innovation Credit" and "Skills Credit". Innovation credits include participating in scientifically research projects, extra-curricular practice links, subject competitions, publishing academic papers, obtaining awards for Subject Competitions and other award credits; skill credits include award credits for skill competitions, obtaining skills certificates and other award credits. Encourage students to participate in innovative and practical activities, cultivate demonstrativeness thinking and practical ability, and improve students' scientific literacy and practical ability.

\subsection{Improving teaching conditions and providing funds to support teaching conditions are the basis of cultivating comprehensive quality and innovative ability}

Fijian Institute of Engineering takes teaching conditions as basic engineering to carry out key construction. It cooperates with enterprises to build laboratories. Through co-construction of laboratories, simulate the engineering environment on site, and implement comprehensive training, comprehensive application ability and post adaptability can be improved. The school also arranges 500,000 yuan teaching and research fund, 200,000 yuan student experiment and innovation project fund and 200,000 yuan subject competition fund every year to provide financial guarantee for the comprehensive quality and innovation ability training of applied talents.

3.3 To cultivate high-level teachers and encourage teachers to participate in nonscientific and technological innovation activities is the key to achieving teaching objectives and improving teaching quality

Fijian Engineering College lists the construction of teachers as the "three major construction projects" of the school, which requires teachers to pass the teaching, scientific research and practice barriers; encourages and organizes teachers to actively participate in the research and development 
of engineering projects and engineering practice exercises in school enterprises; encourages teachers to participate in nonscientific and technological innovation and guidance of academic competitions, and makes outstanding contributions to teachers' evaluation, appointment and positions. Inclination in promotion, etc.

\subsection{Creating innovative culture}

Create an innovative culture, encourage innovative activities to show the historical process of discipline evolution, technological progress and professional development in the form of words, pictures, models and objects, so that students can understand the development of professional technology from entering the school gate, be influenced, nurtured and spiritually inherited by engineering culture, and foster tenderheartedness of "big project". Organize in-school academic competitions and scientific and technological innovation activities, create an atmosphere of scientific and technological innovation through network, radio and outdoor publicity, activate the atmosphere of innovation and stimulate innovation enthusiasm. Organize students to participate in national and Provincial University Countersubject competitions, so that students have more opportunities to exercise and practice. To organize reports and seminars of subject competitions to carry out typical propaganda, recognition and summary so as to stimulate enthusiastically for innovation.

\subsection{Application-based curriculum content adjustment}

In dealing with curriculum content, the principle of sufficient knowledge and application first is emphasized. It does not require the systematic and completeness of this course, but determines the choice of knowledge according to the denuclearizing conditions and abilities, as well as the needs of the follow-up courses and teaching; after-class matching exercises and practical thematic training to train students' ability to apply knowledge to analyze and solve problems. In the form of "theory teaching + special lecture", professional and technical personnel of enterprises are invited to bring practical projects of enterprises into the classroom, so as to teach students to analyze, research and propose solutions to practical problems.

Building a platform for cooperation between industry and University Establishing A platform for cooperation between industry and university, realizing the docking between school and enterprise, breaking the closed school-running mode of universities, investigating and analyzing the influence of regional industrialization process and industrial structure adjustment on engineering education, predicting the changes in the quality and ability requirements of applied talents, establishing a communication and communication platform for stakeholders in engineering education, and participating persons such as industry organizations, enterprise organizations and professional organizations. Revision of talent training program and curriculum development. For example, in

cooperation with Fijian Domain Science and Technology (Holdings) Co., Ltd., the College adopts the mode of "school + enterprise" to explore the training of applied talents of information and communication; in cooperation with Fijian Antiphon Information Industry Company, it adopts the order-based training mode to explore the training of applied talents of computer software.

\section{Conclusion}

To sum up, in the process of training applied talents, we should take the innovation of education and teaching as the main purpose, improve the traditional practical education mode, create a unique innovative practical education teaching system of new undergraduate colleges and universities, take the cultivation of applied talents as the objective condition, constantly open up an innovative pattern 
for the teaching practice of applied talents, relying on favorable factors such as society and enterprises, and serve as applied talents. The cultivation of talents builds an efficient bridge of communication, so as to reserve more high-quality applied talents for the construction of our socialist society.

\section{Acknowledgements}

Research and Exploration on innovative quality training of applied talents in Western Province Education Reform Project (17BY117);

Education Science Planning Project of Shaanxi Province < Research on innovative quality training system of Applied talents in Newly-built undergraduate Colleges and Universities (SGH18H570)

\section{References}

[1] Chen Ding. Brief analysis of knowledge, ability and quality structure of engineering application-oriented undergraduate talents [J]. Journal of Nan ping Teachers College, 2007 (2).

[2] Chou Hangzhou, Wang Cavendish, CAI An and Bhang Hui en. Constructing a practical teaching system for training high-quality engineering application-oriented talents [J]. Laboratory Research and Exploration, 2010 (12).

[3] G Tianjin, Ding Xingu, Gunning, Wei Xian. Exploration on the reform of Engineering application-oriented talents training mode in undergraduate colleges and universities --- Based on the thinking of the experimental area of Engineering application-oriented talents training in electronic information of Beguiler University of Electronic Science and Technology [J]. China Higher Education Research, 2012 (1).

[4] Bu Dali. Exploration on the "integration" training mode of engineering application-oriented talents [J]. Journal of Inhuman University of Science and Technology, 2012 (1).

[5] Ciao Angelia. Construction of Engineering Application-oriented Talents Training Course System [J]. Value Engineering, 2011 (29). 